Selusi Ambrogio*

\title{
Secular Reason as a Tool of the Early Jesuit Mission to China
}

https://doi.org/10.1515/asia-2018-0003

\begin{abstract}
This paper provides an investigation into Jesuits' use of secular dialectical strategies during the early part of their evangelization mission in China. In order to prove the relevance of rhetoric stratagems - i. e. scientific verification, logic and universalism of norms - in their attack against Buddhism, this article examines a neglected text, Posthumous Disputes (Bianxue yidu 辯學遺牘). While the Posthumous Disputes (PD) was improperly attributed to Ricci, it is a prime example of Ricci's accommodation method. Documenting the first real confrontation between a Buddhist and a Christian in China, this text provides an extraordinary window into the first dispute between Europe and China. The secular method of accommodation modelled by Ricci to convert Chinese literati was grounded in the universality of reason that he inherited from Aristotle and Aquinas and the fascination with Western science and techniques. The author uses the universality of reason to both reject Buddhism and Daoism as irrational, unscientific, and non-universal and to present the Christian faith as the most rational doctrine.
\end{abstract}

Keywords: Jesuits, Ricci, Secularism, Buddhism, Universalism, Thomas Aquinas

\section{Introduction}

This article investigates the consistency of the Jesuits' secular attitude in converting the Chinese literati. They tried to convert the Chinese in a top-down way using Western cultural strengths rather than by preaching the only true religion. As Mignini ${ }^{1}$ explains, Ricci's strategy in China was sixfold: 1 . To make Christianity authoritative through Western science and techniques that were appreciated at the Ming court; ${ }^{2}$ 2. To show that Christianity is a perfect social

1 Mignini 2016: 265-266.

2 On the relevance of science and techniques in Ricci's conversion process see, among many texts, Laven 2011: ch. 4; Saraiva 2008 Gernet 1985: ch. 1.

*Corresponding author: Selusi Ambrogio, Università degli Studi di Macerata, Dipartimento di Studi Umanistici Lingue Mediazione Storia Lettere Filosofia, via Illuminati, 4, 62100 Macerata, Italy, E-mail: aselusi@yahoo.it 
asset able to guarantee peace and social stability; 3. To lay the logical and philosophical foundations for a concrete introduction of Christian faith as a future step; 4. To suggest comparability between China and Europe in issues such as history, political relevance, economy, and culture; 5. To show that ancient Chinese teaching supported the idea of a personal and transcendent God (i. e. exegesis); 6. To assume the values of Chinese learned men (i. e. Confucianism) in theoretical demonstration. ${ }^{3}$

These tenets of conversion are secular since they do not directly reference belief, faith and revelation. Certainly, this strategy was a first step for the Jesuits, who thought religious conversion would follow. However, after Ricci's death, cultural changes in both China and Europe - persecutions in China and the rise of powerful opponents to the Jesuits in Europe - would create challenges for the order and prevent executing this religious leap forward. As a result, this "secular approach" to the conversion of China - i. e. the first stage - remained the prevalent approach for the Jesuit mission. This secular approach provided a model of a secular civilization, in which religion was completely unrelated to power, and social justice was granted. The "secular approach" also caused Ricci's accommodation method to be rejected afterwards. Although Ricci's appreciation of Chinese culture was part of his strategy, this ideal of a pure, rational and pious society spread all across Europe, and the Sorbonne theologians condemned Ricci's approach on 18 October 1700.

It seems self-contradictory to define a method of evangelistic conversion as "secular"; however, while Ricci's secular approach was not exclusive, it was prevailing and is very interesting since Enlightenment and modern secularism are strictly connected to an understanding or trope of the "Philosophical China" among European thinkers, which either assimilated this understanding or rejected it. Rogacz, to quote just one of the most recent pieces of research on "Chinese secular spirit", shows that the birth of modern European secularism, particularly in historiography, has China as its source. ${ }^{4}$ This article demonstrates the strategic consistency of Ricci's secularism. Ricci's Jesuit successors were very deeply convinced of the efficacy of this method and acted as "secularist polemicists”, something unprecedented in late 17th and early eighteenth Century Europe. Ricci and his successors used this secular approach to strategically erase Buddhism by proving its inconsistency with logical argumentation and scientific proofs. They did not use the Bible as God's revelation of the only Truth as a dialectical tool; since China is not a culture of "one book", it does not share the cultural assumption of the holiness and sacredness of a single text, which, in

3 On Ricci's accommodation method see also Mungello 1989: ch. 2.

4 Rogacz 2018. 
the Europe of the time, is considered the incontrovertible truth, reachable only through conversion and faith.

In our opinion, despite what Criveller suggests, Ricci's Tianzhu shiyi 天主實義 (The true meaning of the Lord of Heaven) is not simply a catechism ${ }^{5}$ but also a dispute. The primary aim of a catechism is to instruct and guide the reader in the process of the cultivation of faith, and it presents Christ as the model for this perfect path. By contrast, some chapters of the Lord of Heaven are harsh refutations of Buddhist doctrines (chapters 2 and 4), and several sections are refined discussions of the similarity between the ad hoc reconstructed Chinese ancient idea of the Lord of Heaven and the European idea of God. As Mignini's argues in his analysis, this book was designed to be both the first step to familiarize Chinese people with European culture/religion and as the final step to reject the "Buddhist sect." Ricci says:

If they were able to argue with each other in a rational manner [zhili 執理] they would naturally be able to distinguish between truth and falsehood; and the three schools would be able to return to the one and only correct Way [...] the religion of the Lord of Heaven. ${ }^{6}$

In Tianzhu shiyi, Ricci acts as a great master of rational thought ready to deliver his teaching, not as a missionary who is preaching a new faith and the holy word. This "secular mode" reaches the apex in the text we analyse, namely the Posthumous Disputes.

\section{The sources of Jesuits' secular dialectics}

Before presenting the text, we want to make clear what we mean by the word "secular". The best way to understand this term is to look at how Thomas Aquinas, who founded this philosophical attitude, uses it. The medieval philosopher provides a clear distinction between what is known by reason and what is known by revelation, which serves as the basis of modern secularism among Jesuits, and was built on by Ignatius of Loyola, the founder of the order. In the "Eleventh Rule to have the True Sentiment in the Church" in his seminal Spiritual Exercises, Ignatius of Loyola writes:

To praise positive and scholastic learning. Because, as it is more proper to the Positive Doctors, as St. Jerome, St. Augustine and St. Gregory, etc., to move the heart to love and serve God our Lord in everything; so it is more proper to the Scholars, such as St. Thomas,

5 Criveller 2013.

6 Ricci 1985: 101 (we added Chinese characters to translation). 
St. Bonaventure, and to the Master of the Sentences, etc., to define or explain for our times the things necessary for eternal salvation; and to combat and better explain all errors and all fallacies. For the Scholastic Doctors, as they are more modern, not only do they help themselves with the true understanding of the Sacred Scripture and of the Positive and holy Doctors, but also, they, being enlightened and clarified by the Divine virtue, help themselves through the Councils, Canons and Constitutions of our holy Mother the Church. ${ }^{7}$

While Ignatius of Loyola suggests that the Fathers of the Church are masters of faith and cultivate a loving heart, he implies that the Scholastic theologians, i.e. St Thomas and St Bonaventure, are the true models of dispute, since their dialectic method can defeat errors and heresies. Loyola here suggests that the best model for argumentation in places like China is Thomas Aquinas's model, because it is effective in defining and explaining the prerequisites of faith for our times, rather than directly providing arguments about salvation or faith in God. In Thomas Aquinas's philosophical system, reason is the first necessary step to reach faith, so it is necessary to discuss reason in order to prepare room for faith. Reason and philosophy explain essential prerequisites for the Christian faith, such as the rational proofs for the existence of God, such as cosmology, the opposition between what is possible and what is necessary, degrees, aim or tendency. This approach completely avoids using the revelation as proof, since faith takes root only after reason ploughs the field. The gradual method of Ricci's conversion is clearly a Thomistic heritage. Therefore, for Ricci, the first step before real conversion is twofold: to convince the Chinese literati that Christianity is endowed with natural reason, and to defeat enemies of the Christian faith, namely Buddhists and Neo-Confucians. Another Thomistic element of this approach is the firm belief that man can perform good actions through his free will and not because of his faith alone. Thus, pagans can be good and virtuous, even though they have not received revelation.

As Kennedy shows, Aquinas's firm belief in the power of "natural reason" is at the ground of modern secularism, explicitly opposed to an all-englobing faith and Church. Aquinas believes that when revelation and reason collide, revelation prevails; however, faith and reason can converge when they are rightly compared.

Thus, we have the two kinds of thinking in two summae, one that could be called secular because it relies essentially on reason and the other theological because it relies on revelation. ${ }^{8}$

Here, the meaning of secular merely means mundane, or of the world (saeculum), ${ }^{9}$ perfectly autonomous from faith or revelation. This understanding of

7 Loyola of Ignatius 1914.

8 Kennedy 2006: 27.

9 2006: 28. 
"natural reason" is clearly derived from Aristotle. The question of universality, therefore, is connected to natural reason:

[Thomas] claims universal, rather than sectarian or private, assent [to the existence of God...]. It is the God of the public rather than the God of the parish-the God of thinkers rather than the God of the people. It is the foundation of faith, not faith itself. ${ }^{10}$

Here, it can be inferred that a "secular" argument has a twofold meaning. On the one hand, the term "secular" implies that this argument does not use religion and spirituality as theoretical proof, but rather draws on logical and empirical evidence. On the other hand, it means that this argument has a significant temporal application, and therefore has universality, because "natural reason" is not limited to an age or a specific civilization.

This twofold definition can be perfectly applied to our Christian debater, who uses science or at least empirical proofs in order to contradict the imaginary Buddhist astronomical system and its theories about transmigration. Furthermore, the debater rejects Buddhist norms, such as the prohibition against killing, providing reasons for these norms not to be universal, in either time or space. Only once during the $P D$ does this debater recall the prestige of the western wise men and the reliability of a "Western Classic" of good reason and morality (i. e. evidently the Bible), however, he never mentions the authority of revelation or the final necessity of faith.

\section{Posthumous disputes (PD)}

The Posthumous Disputes (Bianxue yidu 辯學遺牘) ${ }^{11}$ can be divided into two sections. The first section is composed of two letters, one written by $\mathrm{Yu}$ Deyuan 虞德園 (1553-1621) - also named Yu Chunxi 淳熙 - to Ricci, and the

10 2006: 29.

11 All translations of $P D$ are our own, only a short section has been already translated in Gernet 1985: 217. The first edition available of $P D$ was printed in 1626 in the second volume of Li Zhizao 李之藻, Tian Xue Chu Han 天學初函, [First Collection of Christian Studies], 637-688 (we consulted the photographic copy printed in Taipei in Li 1953). The most recent and authoritative modern textual edition of all the Chinese works by Matteo Ricci is in Zhu 2001; the text and all annexes of Posthumous Disputes are listed under the title Fu Yu Chunxi 復虞淳熙 (Reply to Yu Chunxi) at pp. 653-687. Another diffused edition with comments is in the fourth volume of sixty of Chung 2003. This is a collection of hundreds of Jesuit Chinese writings from late Ming to early Qing in simplified Chinese. This edition, despite many layout issues and a few wrong characters, is available online at CTEXT. We consulted all three editions but quotes are taken from Zhu 2001. We provided pages both of Zhu 2001 and Chung 2003 in this order. 
second is Ricci's reply. These two letters discuss topics related to Jesuits' critics of Buddhism, but are mostly a highly educated and formal exchange, and their philosophical interest is limited. The second part is the dispute and it is the first available dispute between a Christian and a Buddhist monk. While the two letters are incontrovertibly attributed to Yu Deyuan and Ricci, the second part is traditionally attributed to Matteo Ricci, although this seems impossible, given the historical facts. Ricci passed away in 1610, five years before the text of the Buddhist monk was published in 1615. Therefore, this section, which simply follows Ricci's accommodation method as on open defence of The Lord of Heaven was most likely authored by one of his direct successors in the China mission or by one of his early converts.

While previous scholars have identified a couple of possible authors, it seems most likely that the text was written by one of Ricci's European successors. One strong candidate for authorship is Diego de Pantoja (1571-1618), one of Ricci's most faithful European acolytes. Other scholars, like Lancashire who was one of the first to study the $P D$, argue that Xu Guangqi 徐光啟 (1562-1633), the most refined and eminent convert of the early period, ${ }^{12}$ is a likely candidate for authorship. Sun also suggested that the text should be attributed to Xu Guangqi in a detailed article where he argued that the text's author needed to fulfil three requirements: have a good knowledge of Buddhism, be well-versed in western knowledge - particularly astronomy, and hold a clear Confucian stance against Buddhism. ${ }^{13}$ Sun argues that only Xu Guangqi could satisfy these conditions. ${ }^{14} \mathrm{He}$ excluded Yang Tingyun 楊廷筷 (1562-1627), another potential candidate, because of his minimal astronomical competence and the lack of a harsh dialectical attitude in his corpus. Similarly, Sun completely disregards any Jesuit as possible author, likely because it would have been hard to imagine a Jesuit developing a mastery of Buddhist teachings and holding a clearly Confucian position. However, while Sun's analysis is detailed and accurate, it is not fully convincing. The debater in the $P D$ completely mishandles Buddhist cosmological concepts, displaying a weak expertise. Furthermore, the anti-Buddhist attitude that Sun attributes to $\mathrm{Xu}$ could also be the anti-Buddhist attitude common to all Christians - Jesuits or Chinese converts - in China or Japan. ${ }^{15}$

\footnotetext{
12 Lancashire 1968-69: 88.

13 Sun 1994: 44-46.

14 1994: 46-48.
}

15 Also Standaert 1988: 175-182, Zhou 2000 and Zürcher 2001: 158-169 support Xu Guangqi as author of $P D$. Zürcher suggests a close similarity between $P D$ and Pi [Shishi zhu] wang 闢[釋氏 諸]妄 authored by $\mathrm{Xu}$, however, we notice that despite the same anti-Buddhist attitude, the arguments and the literary style of the two disputes are quite dissimilar. More interesting is 
While the purpose of this article is not to suggest a new, incontrovertible attribution, it seems likely that this text was authored by a European for three reasons. The text has an aggressive rhetorical style suggestive of the European disputatio, which makes large use of the law of the excluded middle and the necessity of the universality of norms. Secondly, the author has some deep misunderstandings of Buddhist doctrines that would have been at least unusual for a Chinese person living in the holistic culture of sanjiao heyi 三教合一 “the three teachings are but one”; even a declared enemy of Buddhism like Xu would not have made some of the errors found in the $P D$. Finally, there are a few expressions in the $P D$ that are incongruent with Chinese culture of the time, but that would make sense when written by a European missionary. For instance, the Christian says that "you need to pass through India to go to China” (印度去 中國甚進) and that this journey is an easy one (求之不難). This sentence is formulated to suggest that it is so uncomplicated to go to India and that a direct exchange with Brahmans is possible. Such a claim is imbued with a Jesuit cosmopolitanism that a recent Chinese convert could hardly show. Pantoja seems to be one of the likeliest author, not only because of these factors, but also because after Ricci's death, he was likely the strongest advocate of his method, and because the Christian discussant in the $P D$ mentions three works written in Chinese with the aim of spreading Christianity: The Lord of Heaven, Ten chapters of a Strange Man both by Ricci, and Seven Victories (Qike 七克) by Pantoja, first published in the early 1610s. ${ }^{16}$ The possibility of a collective authorship by $\mathrm{Xu}$ and Pantoja - or another Jesuit - is another likely and intriguing theory. ${ }^{17}$

Standaerts's discussion of the preposterous legend of Lianchi's death-bed conversion to Christianity thanks to Jesuits' rejection of his teaching.

16 On the date of Seven Victories Waltner reports 1604 (Waltner 1994: 431). However, this is likely to be misprint and it should be 1614. According to the Chinese Christian Texts Database (CCT) of KU Leuven institution of research, the text was written in the early 1610s (http://heronnet.be/pa_cct/index.php/Detail/objects/1312).

17 CCT has c.1624 for the date of publication of $P D$ (http://heron-net.be/pa_cct/index.php/ Detail/objects/10207), however this late date raises a few doubts: 1 . The Christian disputer never mentions the Nanjing Church incident of 1616-1617, a good rhetorical point against the intolerance of contemporary Confucians (those not following the original true teaching of Confucius, i. e. the Lord of Heaven); 2. Since the first edition of the text is published in 1626 - in the aforementioned Tianxue chuhan -, such a recent writing and clearly wrong attribution to Ricci is less plausible; 3 . The first two letters are likely original. WaS the third section attached after more than 15 years after their writing? 


\section{Buddhist dialectic and aim}

The second part of $P D$ is composed of four sections, each of which opens with a short chapter taken from Three Notes of the Bamboo Window (Zhuchuang sanbi 竹窗三筆), which was written by the (Chan and Pure Land) Buddhist Monk Lianchi 蓮池 (1535-1615) ${ }^{18}$ and published soon after his death. The monk read The True Meaning of the Lord of Heaven by Ricci, which is, as we have said, largely an open attack against Buddhist tenets (i. e. transmigration, emptiness, meditation, the nature of Buddha, the humanity of Buddha, etc.). He claims to have been forced to reply because Christians were menacing the stability of the Empire and ridiculing Buddhist teaching. Thus, he inserted into his doctrinaire writing these four critical chapters on Christian doctrine - or, more accurately, a critique of the criticisms of Christians on Buddhism - he titled Tianshuo 天說 On Heaven, understanding Heaven as the teaching of Heaven, namely Christianity. The Buddhist monk makes use of strategies typical of Buddhist rhetoric or dialectic, such as belittlement of the opponent (i. e. a Christian who participates in his lessons), the "rhetoric of menace" for the stability of the Empire and dharma and a mild but evident use of the authority of a renowned master as he was. ${ }^{19}$

In $P D$, the Buddhist presents four reasons to reject Christian teaching. The first is that the Christian God is a low and mundane God. The monk identified Him with the god Indra who ruled over the daoli tian 忉利天, also named sanshisan tian 三十三天, namely "the [level/sky] of the thirteen devas", in Sanskrit trāyastrimsía. ${ }^{20}$ A world has several more perfected levels and each world is ruled by a god, i. e. Brahma, while a Buddha is the ruler of a constellation of a billion worlds, namely the daqian shijie 大千世界, which we could translate as the "big chiliocosmos". ${ }^{21}$ Secondly, the killing of any being is unacceptable, not only because the life of any being is relevant, but more importantly because this act poisons humans and prevents the clarity of mind necessary to reach enlightenment. Thirdly, since Jesuits ceaselessly advocate that Confucian teaching is perfect and, from the point of view of moral and social doctrine, very similar to Christianity, the monk suggests that there is no need for this new teaching. Fourthly, Jesuits' rejection of Buddhism is due to

18 Lianchi is his Buddhist master name. His personal name is Shen Zhuhong (沈祩宏).

19 On Buddhist, particularly Chán, rhetorical strategies see Anderl 2012a2012b Braarvig 2012.

20 See the entries in Soothill/Hodous, A Dictionary of Chinese Buddhist Terms. The trāyastrimśa is the second lowest heaven in a cosmology of twenty-six.

21 A one thousand worlds is a "little chiliocosmos", a one million is a "medium chiliocosmos" and one billion of them is named either a "big chiliocosmos" or a "trichiliocosmos". 
their complete ignorance of this teaching, the lack of a true vision of the world behind the mundane aspect of reality. They support the "immortality of souls" but reject "transmigration", therefore the monk asks where these souls go and stay. As it is evident from these four rejections, the Buddhist's quest is always enlightenment, which is the perfect control of passions and thinking, in order to understand the truth behind reality, which can only be reached by emptying the mind. In these chapters, the reader would have the sense that the Buddhist disputer lacks a strong logical and argumentative analysis; however, this lack likely stems from the fact that the Buddhist is seeking to help his reader attain enlightenment, rather than providing incontrovertible rational explanations. Since he is debating with his opponent as a scholar, he does not seek to win his opponent over. He does not exert any authority other than the reliability of his teaching for both enlightenment and social stability.

When the Christian who participates in his lessons and raises critical questions goes too far in discussion and point scoring, Lianchi asks him to be cautious, not because his behaviour is not respectful, but rather because his reasoning could penetrate the minds of simple people and pollute their hearts. In one section of chap. 2, the monk almost loses his temper and defines his opponent's arguments as follows:

This raising of those kinds of problems is what [we] call a pedantic and punctilious shortcircuit, only designed to destroy the good teaching of the great Dao, what is their aim? Furthermore, their [of Christians] books fabricate so many rootless arguments, that it is impossible to mention all of them. ${ }^{22}$

His opponent is pedantic and only tries to hide his arguments' deficiencies through sophisticated observations. Lianchi is right, since the Christian is here advocating that divination was introduced to China by Buddhism and that it is a fraudulent and preposterous activity. It is true that the monk quoted divination, but he did so simply to show that even the ancient Chinese since the Liji 禮記 and Zhouyi 周易 believed in rebirth and used divination in order to remove any doubt about former lives. The Christian, instead of suggesting that ancient Chinese divination and rituals devoted to ancestors were not necessary due to rebirth, made an accusation of superstition and fraud. This argument is perfectly consistent with Ricci's idea of the philological reversal of a kind of Chinese "perfect and pure ancient teaching" of the Lord of Heaven. Divination is rejected as impure teaching and thus immediately attributed to the usual enemy.

22 如斯設難, 是謂騁小巧之迂譚, 而欲破大道之明訓也, 胡可得也? 復次彼書杜撰不根之語, 未易悉舉。(PD 670/279). 
A second instance of the monk's rejection of his opponent's critics to Buddhism is in chapter four, again on the subject of divination. The monk, evidently exasperated, says:

Speaking about divination, you take things from everyday life [i.e. mundane life], you elevate them to be [absolute] instances and you hide and cancel the true logical process of reasoning (因明 ${ }^{23}$ ) speaking cryptically. You deliver a session of teaching on fictitious truth that we might say is like a glass of wine that causes ridiculous talk or jokes and funny performances. However, this penetrates into the ears of simple people and remains in their hearts: the evil it causes is not insignificant, this is why words must always be cautious (慎). ${ }^{24}$

He unmasks the dialectical strategy of the Christian who a word by word discussion makes of each of his statements and takes any argument to extremes. The Buddhist monk instructs people wishing to gain peace of mind, while this man has come to pose questions which have nothing to do with "the path of freedom". According to Lianchi, Christians are attached to a worldly minor god and just want to win a debate.

\section{Strategy of logic and scientific verification}

As we already reported, the Buddhist monk in the first chapter suggests that the Christian God, i. e. the Lord of Heaven, is but the low ranking god Indra of the "level of thirty-three devas" sanshisan tian 三十三天, where devas, in Chinese tian 天, are the minor deities of the Indian pantheon, often chthonic, and not "thirty-three skies" as the disputer understands it. In his reply, the Christian observes that Lianchi's discussion is cursory and weak. The first point he raises is that the Lord of Heaven of Buddhists and that of Christians is absolutely not the same. For Christians, to celebrate the Lord of Heaven means "to worship the Lord of Heaven as a Lord” (敬天主以為主也), thus as unique, excluding any further deity. To celebrate several lords is to celebrate nobody; therefore, Buddhists claim to serve and celebrate a God, but they do not, since their pantheon is full of deities. The Christian Lord/God is the only creator of the

23 Yinming is the Chinese for Hetuvidyā: the Buddhist science of Logic or even epistemology, based on direct perception, inference and syllogism (see the entry "hetuvidyā" in Buswell 2014). This epistemology does not forsake knowledge of reality, instead it searches the detachment from reality in order to achieve enlightenment.

24 卜之云者, 姑借目前事, 以權為比例, 蓋因明通蔽云爾。子便作實法會, 真可謂杯酒助歡笑 之迂譚, 俳場供戲譃之諢語也。然使愚夫愚婦, 入乎耳而存乎心, 害非細也, 言不可不慎也。 (PD 676/285). 
world, the source of all love, the origin of happiness and bliss, the only supreme judge of reward and punishment. The one God has to be one and only, because the principle ( $l i$ 理) of everything in the world is just one, as one is the beginning:

Since we believe that Lord of Heaven is the Lord and you believe that Buddha is the Lord, according to the principle, there cannot be two Lords as there cannot be two truths. ${ }^{25}$

This is a clear adoption of the law of the excluded middle, and there are several further instances of that law. For example: "They consider Buddha to be the Lord, thus our [God] to be none." 26 This argument is clearly grounded in the assumption that the principle, according to Aristotle's philosophy of the unmoved mover or prime mover, could but be unique. This thesis is taken by Thomas Aquinas as the first reason for, or proof of, the existence of God, and it is presented as following "natural reason”. Aquinas presupposed that Aristotle's philosophy, although not a religious philosophy, was natural and thus universal in itself. Aristotle is the emblem of the pagan correct and moral "natural reasoning" that is the grounds for faith. However, the Buddhists do not believe in a prime mover and worship several levels of godliness. None of these gods is a creator, not unique and not superhuman. They are simply perfect and enlightened beings, some humans. Here we have a clear clash with the concept of "natural reason". For the Christian disputer, two Lords of Heaven are logically and cosmologically unacceptable. Buddhists are wrong and preposterous.

Since there is just one God, the Christian must demonstrate the greater reliability of the Christian thesis and nothing is better than science in order to prove that Christian faith is perfectly in accord with reason which is common to all humans according to the Aristotelian tradition. Whereas Ricci also uses the fifth method we quoted from Mignini, i. e. exegesis, the disputer here uses only science and logic as incontrovertible judges. Since Buddhists do not revere the Confucian classics, he prefers to appeal "natural reason" alone, using science as the empirical face of reason.

The Christian suggests that Buddhist arguments about the "four continents", the four parts of the earthly world, and the "level of the thirty-three skies" - as he understands it - are acceptable. He says that, actually, it is only recently that the fifth continent has been discovered and, therefore, before the sixteenth Century, they were thought to be four. About the "sanshisan tian 三十三天”, he evidently wrongly understands it as a plurality of skies, whereas tian 天 here

25 故我以天主為主, 汝以佛為主。理無二主, 即無二是。(PD 665/273).

26 彼以佛為主, 宜以我為非。(PD 665/273). 
means devas. Therefore, his reasoning is based on the concept of "thirty-three skies" and not of "[the sky/level of the] thirty-three devas". In order to prove the correctness of this idea, he shows great knowledge of both Western and Chinese astronomies. He provides confirmation of it, taking into account the elliptical planes of the planets which come to approximately the same number. Although he confirms this concept, he wants to distance Buddhism from any grounded reason. Therefore, he remarks that these ecliptics can be measured thanks to the Arabian astrolabe, and not through meditation. He argues that the Buddhists completely ignore the original scientific reason for these numbers, since they simply received this knowledge and covered it with absurdities and erroneous theories.

On the contrary, he argues that the big chiliocosmos (daqian shijie 大千世界) ruled by a Buddha completely lacks any scientific confirmation. He claims it is a Chinese Buddhist fantasy since nobody has ever seen or measured it, apart from Buddha himself. ${ }^{27}$ To support this argument, he wisely reports that in India, which is the source of Buddhism and where the same Jesuits preach, nobody has ever heard of this theory. The big chiliocosmos is an awful mixture of yin-yang 陰陽 theory, Daoist and Buddhist fantasies. In effect, Chinese Buddhism is a mass of doctrines, where the few good principles are hidden by the most despicable opinions. For instance, as Ricci advocated in all his works, the retribution of good and bad actions is but the Christian doctrine of reward and punishment, while rebirth or transmigration is a reinvention of Pythagoras's metempsychosis. For anyone who searches for proof of what he says about the inexistence of big chiliocosmos, there is a simple solution: he can go to India, which is easily reachable from China, and ask the Brahmans, as the Jesuits already have. Having scored his point, the disputer argues that Buddhism incontrovertibly fails empirical verification, since "it is completely impossible to verify if it is so" 28 .

\section{Strategy of universality}

In the definition of the meaning of secularism, we mentioned two prevailing aspects: the use of scientific and technical/logical reasons (avoiding religion and spirituality) and the necessity of common and universal norms. Ricci and his disciples, including the author of the $P D$, inherited these Aristotelian realist universals through Aquinas. The disputer accuses Buddhism of being unable

27 He says: 不知孰見之, 孰數之? (PD 666/274).

28 未尝真見其然 (PD 674/283). 
to produce any universal and stable theories or norms. In the AristotelianThomistic philosophy that grounds this approach, this incapacity demonstrates the fallacy and weakness of Buddhist doctrines. In this text, universalism - that is the universality of "natural reason" - is used in a twofold way. Firstly, it is used to support Christianity as the only truly universal doctrine because it is perfectly compatible with reason. Secondly, universalism is used to reject any thesis which does not apply to all possible circumstances (i. e. which are not universal).

In the second chapter, the Buddhist monk argues that Jesuits claim that Confucian teaching, through Confucius and Mencius, is the perfect teaching of Heaven. Therefore, why does China need Christianity? The Jesuit's reply is twofold. The first response, which is repeated several times by Ricci in his writings, is based on the incompleteness of Confucian teaching because of the burning of books during the Qin Dynasty. The ancient books provide only partial teaching, and therefore, it is necessary to restore, reconstruct and "cleanse" this teaching of the deviations caused by Daoism (Huang-Lao), yin-yang theory and Buddhism. The Jesuit argues that at that time, this corruption in China meant that only few people truly were following the teaching of the Lord of Heaven and celebrating the Lord of Heaven according to Confucius.

The second part of the Jesuit's reply is subtler and more dangerous; it focuses on how the same Confucian teaching is universal in terms of celebrating the proper Lord of Heaven, but it is not truly universal because it has not been given to everyone, in contrast to Christianity. He argues:

I am fully convinced of the fact that truly the ancient kings and wise men said to celebrate Heaven, to respect Heaven, and so on. However, they applied that alone, for their own sakes, and they did not universally (公) teach all humans to do so. There will certainly be a time when everybody will devote himself to do so. Only then they will be truly acknowledged as ancient kings and wise men. If in the world every person respects and worships [Heaven] - everybody, every day, in every moment, in every word, in every thought - and does not commit any violation against Heaven not even of the size of a pinhead, this and only this will be concretely what the ancient kings and wise men had explained and taught. Nothing would stay incomplete and truly it would be possible to finally declare that nothing needs any improvement and it is not necessary to expect the creation of a new doctrine. If this is not the case, then the wish of the ancient kings and wise men will not be realised, and consequently it will be necessary to wait for posterity for completion. Therefore, if Yao, Shun, Confucius and Mencius lived nowadays and had the responsibility of the governance of all the peoples and creatures, they would be conscious of the fact that the desire of a venerable faith is still to be satisfied and they would try to cope with that, as food satisfies hunger and drink thirst. After having heard that there is a doctrine of the Lord of Heaven taught by masters that teach all men the respect and worship of Heaven, they would encourage them to convert with a sincere heart to this teaching and they would pray to God to bless their people. They would make it impossible that any day anyone 
would commit any transgression against Heaven. It is certain that they would do so. Following our books and debates, they would discuss together and, finally, they would confide with veneration in the powerful path of faith. Can we actually argue now that there was no expectation of a new doctrine? ${ }^{29}$

While the ancient kings taught a personal path of perfection which was the individual achievement of good nature (xingshan 性善) and inner wisdom (neisheng 內聖), they did not teach a doctrine open to the whole of humanity. The elitist and exclusionary nature of their otherwise good teaching prevents it from being universal - unlike Christianity, which is effective because it is addressed to the whole of humanity. ${ }^{30}$ For the Jesuit, Christianity is the fulfilment of the teachings of Yao, Shun, Confucius and Mencius. The Christian disputer adds that this expectation of a perfect doctrine could never be fulfilled by any other teaching, like Buddhism, since only Christianity is perfectly coherent and is attributable to God - although he never openly mentions "revelation". On the contrary, anybody can suggest a new Buddhist theory which does not need to fit with all other teachings.

At the end of the fourth chapter, the Jesuit uses the intriguing term changfa 常法, which has a long philosophical history in China. He writes that the Buddhist prohibition of killing is "fei shishi tongxing zhi changfa 非世世通行之 常法”, literally “is not a common norm/praxis (常法) effective (通行) continually in all epochs (世世)”. The term changfa has been used by several schools of thought in ancient China, ${ }^{31}$ particularly it is at the centre of Legist school (i. e. Hanfeizi 韓非子 +233 BC). We have to consider that, in this school, the concept of

29 夫帝王聖賢言事天、畏天等, 信有之。然帝王聖賢自為此, 必教人共為此, 又必期人人盡 為此, 然後謂之帝王聖賢耳。今天下果能人人昭事奉若, 人人日日事事言言念念, 皆無毫毛過 失獲罪於天, 則 聖賢帝王所言所願, 無一不滿, 真可謂無所不足矣, 真無俟創為新說矣。若猶 未也, 則帝王聖賢之志, 此時尚為未遂, 果有待後人之足之也。然則堯舜孔孟而在今日, 撫此 民物, 自知欽崇奉若之志未為暢滿, 必將求所以滿之之術, 如飢於食, 渴於飲焉; 聞有傳述天 主之教，教人欽崇奉若，牉民使歸誠於天主，祈天主願降佑於民，究將使人人日日果無獲罪於 天者, 必且速致之; 按其書與言, 必共討論之, 論之而當, 必尊信力行之, 何謂不俟新說乎? (PD 674/283-4).

30 On the universal attitude and psychology of Jesuits' missions around the world see Clossey 2008: 97-100. "The Jesuits, however, attempted to combine the old dynamism with the new stability. Nadal describes a missionary "journey" as itself as "the most ample "place," one which "reaches as far as the globe itself ... the most glorious and longed-for "house' for these theologians." The Jesuits' goal is "to procure the salvation and perfection of all women and men. They understand that they are to that end bound by the Fourth Vow to the supreme pontiff: that they might go on these universal missions for the good of souls by his command, which by divine decree extends throughout the whole church."' (2008: 97).

31 For a comparative analysis of all the different meanings of $f a$ 法 in the history of Chinese thought see the several related entries in Zhang 2014. 
law ( $f a$ 法) is very different from the Christian concept of law or norm. Legists, openly opposing Confucian "traditionalism" argued that for a norm to be good, it does not have to descend from a superior authority (i. e. heaven tian 天) or from an historical tradition. A norm has simply to be effective. When it is not, it must be abrogated. Therefore, the most important meaning of changfa is clearly not compatible with the Western concept of universality, which is always connected to truth, usually transcendent or even divine, descending from Aristotle's theory of the universals. For Legists, the norm is simply applied to anybody but not at all times. It has no truth in itself. It can become untrue. The second school that used this term is Buddhism, since $f a$ is the Chinese term for dharma, the doctrine taught by the Buddha.

In the same closing part of the whole Posthumous Disputes, the Christian uses the following expressions with changfa: "fei renren tongxing zhi changfa 非人人通行之常法” (this is not a universal norm which applies to everybody), “fei wuwu tongxing zhi changfa 非物物通行之常法” (this is not a universal norm which applies to every being). He explains:

If ours wasn't a great universal [norm] effective all-over the world from antiquity to today, how could we consider its violation a serious transgression and a tragic sin all-over the world from antiquity to today? ${ }^{32}$

Here, it is important to understand that for Christians, universality is not only a logical necessity, but also a social one. The universality of ethical and religious norms is necessary in order to guarantee the certainty of punishment and reward, if not during this life, so in the afterlife. A norm lacking universality is useless and dangerous for social stability. For the Buddhist monk, the universality of his prohibition of killing is based on transmigration, while the Jesuit builds the whole reply on the inexistence of transmigration. Therefore, according to the Christian, the Buddhist doctrine is demolished, since its norms are not universal.

Because the idea of rebirth, taught in Buddhism since the time of Gautama (the historical Buddha), was based on the empirical observation of the natural cycle of life and death and the Christian concept of the immortality of the soul is a clear logical assumption based on the judicial necessity of punishment and reward in the afterlife, both can be seen as universal principles. This empirical grounding of the cycle of death and rebirth in Buddhism is shared with Chinese ancient thought, since this common principle of life is named $q i$ 氣, the universal

32 夫我之法, 既不可為天下古今之大常, 犯之者又焉得為天下古今之大過大惡哉? (PD 679/ 288). We interpret this sentence as a rhetorical question, therefore, in this case, we follow Chung 2003's punctuation. 
energy. The Song and Ming Neo-Confucians, harshly attacked by the Jesuits as atheist deviant Confucians, maintained a universal thought open to all beings, a thought based a humanitarian attitude towards everything around us, particularly so in the teachings of Zhang Zai 張載 (1020-1077) and Wang Yangming 王陽明 (1472-1529). It is thus simply not true that Buddhism is not universal. What would be more correct to say is that Buddhism is not logically universal. Whereas the denial of the big chiliocosmos is perfectly reasonable, since this concept is a deduction and abstraction (although Buddhist infinity of the cosmos is proved by astronomy) the rejection of rebirth is not very consistent with science and empirics since it is based on the immortality of souls, which is again grounded in judicial and not in scientific reasons.

\section{Conclusions}

As we have illustrated, the dialectics of scientific proof - particularly astronomy -, logical arguments - i. e. law of excluded middle - and universalism are the prevailing aspects of $P D$. The Christian seems to be a "secular polemicist" who aims to prove that science and the universality of norms are the only reasonable criteria for truth. In China, Christianity suffered from comparison with any heterodox doctrines, such as the White Lotus and Non-Action movement, which were spiritually and politically deviant. As Gernet reports, ${ }^{33}$ Christianity had been included within the group of xiejiao 邪教 (deviant sects) already by 1616 with Shen Que's memorandum, the grounds for the first Christian persecution in the Chinese Empire. Therefore, the missionaries and their early acolytes were reasonably preoccupied and worried by this assimilation. The “deviant doctrines" were usually presented as dangerous, since they disrespected the imperial power, subverted hierarchy and denied the ritual of Heaven as an imperial prerogative. Christian organization and practices were clearly deviant from the imperial point of view. This is the historical reason for missionaries being so secular, so focused on social stability and on the celebration of science, rather than on explaining the religious tenets of Christianity. Aquinas provides the ideological foundation for this secular method, while the historical context explains Jesuits' avoidance of direct religious preaching. In effect, the direct preaching of minor orders entering China and the change in the China Jesuits' method of evangelization were the cause of the final failure of this mission in the second half of the

33 Gernet 1985: 115-116. 
seventeenth Century. In short, we can say that, unlike the Jesuits had hoped, the first step of this process of evangelization was not followed by the second and final step of conversion.

The $P D$ is a clear manifestation of a long-term strategy of conversion. This strategy began with Ricci's change of robes, from the Buddhist tunic to the elegant and sophisticated robes of Chinese scholars. Secularism was a necessity in order to facilitate penetration into China. The prerequisite of this strategy was the universalism of "natural reason". A reason which can be supported by evidence, (astronomic) measurement, logic, and certainty of justice. The Jesuits clearly perceived the great fascination of Chinese with their techniques and scientific explanations. They were considered scientists rather than missionaries. However, the Chinese learned men, although attracted by their scientific exhibitions, were not as easily persuaded that Westerners, and specifically Christians, were able to penetrate beyond the measurable surface of reality. Lim reports that

Fang Yizhi in his famous remark in the preface to his Wuli xiaozhi [物理小識]: 'The learning from the Far West is detailed in zhice, but deficient in speaking about 'tongji'. This being so [...] their zhice is still not adequate'. ${ }^{34}$

Fang Yizhi 方以智 (1611-1671) divided Chinese study into three fields: zhice 質測, the investigation of reality, i.e. natural sciences, zaili 宰理, the study of social and moral norms, and finally tongii 通幾, the complete investigation of the reasons of change. ${ }^{35}$ He acknowledged Western thought to have reached a good quality of zhice, although still insufficient. However, in his view it completely lacked any understanding of the reason or principle (li 理) behind reality, which is the most relevant among the three fields of study. Jesuits' preoccupation with convincing the Chinese through objectivity as the measurable and the universal in the most secular fashion, only convinced them of the shortcomings of European philosophical and doctrinal capacity. ${ }^{36}$ In this dispute, both the "exclusion" of China from philosophy as unphilosophical - in Kantism and Hegelism -, and the opposed late Qing theory of zhongti xiyong 中體西用 - adopting Western knowledge for its practical uses while keeping Chinese values as the core - find their early sources.

34 Lim 2008: 145.

35 See Kang 2003.

36 On the reactions against Christian doctrine, see Gernet 1985. 


\section{Bibliography}

Anderl, Christoph (2012a): “Zen Rhetoric: An Introduction”. In: Zen Buddhist Rhetoric in China, Korea, and Japan. Edited by Christoph Anderl. Leiden/Boston: Brill, 1-94.

Anderl, Christoph (2012b): “Coming to Term with Terms. The Rhetorical Function of Technical Terms in Chán Buddhist Texts”. In: Zen Buddhist Rhetoric in China, Korea, and Japan. Edited by Christoph Anderl. Leiden/Boston: Brill, 205-236.

Braarvig, Jens (2012): "Rhetoric of Emptiness". In: Zen Buddhist Rhetoric in China, Korea, and Japan. Edited by Christoph Anderl. Leiden/Boston: Brill, 95-120.

Buswell, Robert E., Jr., Lopez, Donald S., Jr. (2014): Princeton Dictionary of Buddhism Princeton: Princeton University Press.

Chung, Andrew 郑安德 (2003): Mingwei Qingchu Yesuhui sixiang wenxian huibian 明未清初耶 稣会思想文献汇编 Beijing 北京: Beijing Daxue Zongjiao yanjiusuo 北京大学宗敎研究所, Vol. 4, 255-290.

Clossey, Luke (2008): Salvation and Globalization in the Early Jesuit Missions. Cambridge: Cambridge University Press.

Criveller, Gianni (2013): “«Un libro fatto tutto di ragioni naturali». Il Catechismo di Matteo Ricci nel contesto della missione gesuitica in Cina”. In: Catechismo (天主实义). Edited by Matteo Ricci. Bologna: ESC-ESD, 15-49.

D’Elia, Pasquale (1942-1949): Fonti Ricciane: Documenti originali concernenti Matteo Ricci e la storia delle prime relazioni tra l'Europa e la Cina (1579-1615). Roma: La Libreria dello Stato, Vols. 3.

Dudink, Ad, Standaert, Nicolas, Chinese Christian Texts Database (CCT-Database) (http://wwwarts.kuleuven.be/sinology/cct), in particular see http://heron-net.be/pa_cct/ index.php/Search/advanced/ccts (09/30/2018).

Elliss, Robert Richmond (2012): "Representations of China and Europe in the Writings of Diego De Pantoja: Accommodating the East or Privileging the West?". In: Western Visions of the Far East in a Transpacific Age, 1522-1657. Edited by Christina H. Lee. Burlington: Ashgate, 101-115.

Gernet, Jacques (1985): China and the Christian Impact. Cambridge: Cambridge University Press. Hsia, R. Po-Chia (2010): A Jesuit in the Forbidden City. Matteo Ricci 1552-1610. Oxford: Oxford University Press.

Jami, Catherine, Engelfriet, Peter, Gregory, Blue (2001): Statecraft and Intellectual Renewal in Late Ming China. The Cross-Cultural Synthesis of Xu Guangqi (1562-1633). Leiden/Boston/ Köln: Brill.

Kang, Ouyang (2003): “Fang Yizhi”. In: The Encyclopedia of Confucianism. Edited by Yao Xinzhong. Oxon: Routledge, 209-211.

Kennedy, Emmet (2006): Secularism and Its Opponents. From Augustine to Solzhenitsyn. New York: Palgrave MacMillan.

Lancashire, Douglas (1968-69): "Buddhist Reaction to Christianity in Late Ming China”. Journal of the Oriental Society of Australia 6: 82-102.

Laven, Mary (2011): Mission to China: Matteo Ricci and the Jesuit Encounter with the East. London: Faber and Faber.

Li, Zhizao 李之藻 (1953): Tian Xue Chu Han 天學初函. [First Collection of Christian Studies], (first edition of 1629, reprinted as photographic copy in Taipei).

Lim, Jongtae (2008): “Restoring the Unity of the World: Fang Yizhi and Jie Xuan's Responses to Aristotelian Natural Philosophy”. In: The Jesuits, the Padroado and East Asian Science 
(1552-1773). Edited by Luís Saraiva, Catherine Jami. Singapore: World Scientific Publishing, 139-160.

Loyola of Ignatius (1914): The Spiritual Exercises by St Ignatius of Loyola. Translated by

E. Mullan. New York: Kennedy\&Sonsby. http://www.companionofjesus.com/se-mullan. pdf (09/30/2018).

Mignini, Filippo (2016): “L'ermeneutica storica dei gesuiti in Cina”. Lo Sguardo - Rivista di Filosofia n 20.1: 261-276.

Mungello, David E (1989): Curious Land. Jesuit Accommodation and the Origins of Sinology. Honolulu: University of Hawaii Press.

Ricci, Matteo (1985): The True Meaning of the Lord of Heaven (T'ien-Chu Shih-I). Translated by D. Lancashire and P. Hu Kuo-chen. Taipei/Paris/Hong Kong: Ricci Institute.

Ricci, Matteo (2010): Dieci capitoli di un uomo strano. Translated by Wang Suna and F. Mignini. Macerata: Quodlibet.

Rogacz, Dawid (2018): “The Birth of Enlightenment Secularism from the Spirit of Confucianism”. Asian Philosophy 28.1: 1-16. http://www.tandfonline.com/doi/abs/10.1080/09552367. 2018.1428051 (09/30/2018).

Saraiva, Luís, Jami, Catherine (2008): The Jesuits, the Padroado and East Asian Science (1552-1773). Singapore: World Scientific Publishing.

Soothill, William E., Hodus, Lewis (1937): A Dictionary of Chinese Buddhist Terms. Delhi: Motilal Banarsidass Publishers.

Standaert, Nicolas (1988): Yang Tingyun, Confucian and Christian in Late Ming China: His Life and Thought. Leiden/Boston/Köln: Brill.

Sun, Shangyang 孙尚扬 (1994): “Bianxueyidu zuozhe kao 《辩学遗虍卖》作者考”. In: Jidujiao yu ming mo ruxue 基督教与明末儒学. Edited by Sun Shangyang. Beijing 北京: Dongfang chubanshe 东方出版社: 40-48.

Waltner, Ann (1994): “Demerits and Deadly Sins: Jesuit Moral Tracts in Late Ming China”. In: Implicit Understanding. Observing, Reporting, and Reflecting on the Encounters between Europeans and Other Peoples in the Early Modern Era. Edited by Stuart B. Schwartz. Cambridge: Cambridge University Press, 422-448.

Zhang, Dainian 张岱年 (2014): Zhongguo zhexue dacidian 中国哲学大辞典. Shanghai 上海: Shanghai cishu chubanshe 上海辞书出版社.

Zhou, Erfang 周駬方 (2000): “Ba “Bianxue yidu” 跋《辩学遗牍》”. Wen xian 文献 2000.2: 215-219.

Zhu, Weizheng 朱維錚 (2001): Li Madou zhongwenzhu yiji 利瑪寶中文著譯集. Shanghai 上海: Fudan Daxue Chubanshe 復旦大學出版社.

Zürcher, Erik (2001): “Xu Guangqi and Buddhism”. In: Statecraft and Intellectual Renewal in Late Ming China. The Cross-Cultural Synthesis of Xu Guangqi (1562-1633). Edited by Catherine Jami, Peter Engelfriet, Gregory Blue. Leiden/Boston/Köln: Brill, 155-169. 